\title{
Gambaran multilokular ameloblastoma dengan pola soap-bubble dan kajian pustaka mengenai variasi gambaran radiografi ameloblastoma
}

\author{
Jatu Rachel Keshenal* , Aga Satria Nurrachman ${ }^{2}$, Azhari $^{3}$
}

\begin{abstract}
Objectives: Ameloblastoma is classified as unicystic, multicystic and solid based on its characteristic. This article is aimed to report a case of ameloblastoma in posterior mandibula, analyze its radiographic appearance and emphasize on describing its other available variations.
\end{abstract}

Case Report: A 39-years-old male patient came to Dadi Keluarga Hospital Purwokerto with complaint of swelling on the posterior lower jaw. The swelling was painless and has been felt since 4 years ago. Asymmetrical face was discovered. On panoramic radiograph, a well-defined radiolucent mass appears with radiopaque septation in the posterior region, the teeth were depressed, the lesion has expanded to the left coronoid process and mandibular notch.

Conclusion: Based on panoramic radiographic examination the image of ameloblastoma in this case is seemed as multilocular in the posterior region, expanding to the left posterior and imaging of multilocular ameloblastoma on the left posterior region showing destruction of coronoid process and mandibular notch with soap-bubble pattern.
${ }^{1}$ Rumah Sakit Gigi dan Mulut Universitas Jenderal Soedirman, Purwokerto Indonesia, 53122

${ }^{2}$ PPDGS Radiologi Kedokteran Gigi, Fakultas Kedokteran Gigi, Universitas Padjadjaran, Bandung, Indonesia, 40132

3 Departemen Radiologi Kedokteran Gigi, Fakultas Kedokteran Gigi, Universitas Padjadjaran, Bandung, Indonesia, 40132

"Correspondence to

Jatu Rachel Keshena

هjaturachel@yahoo.com

Received on: June 2019

Revised on: July 2019

Accepted on: August 2019

Keywords: Ameloblastoma, panoramic radiographs, multilocular, soap-bubble, various pattern Cite this article: Keshena JR, Nurrachman AS, Azhari A. Gambaran multilokular ameloblastoma dengan pola soap-bubble dan kajian Pustaka mengenai variasi gambaran radiografi ameloblastoma. Jurnal Radiologi Dentomaksilofasial Indonesia 2019;3(2):41-6. https://doi.org/10.32793/jrdi.v3i2.489

\section{PENDAHULUAN}

Pembengkakan pada rahang bawah dapat disebabkan oleh lesi jinak odontogenik ataupun non odontogenik. Tumor rahang odontogenik yang paling umum adalah ameloblastoma yang berkembang dari unsur-unsur seluler epitel dan jaringan gigi dalam berbagai fase perkembangan, memengaruhi daerah posterior rahang bawah pada $80 \%$ kasus, khussusnya pada regio molar dan ramus. ${ }^{2}$ Lesi ini tumbuh ekspansif, lambat namun persisten dan dapat menyebabkan displacement ataupun resorpsi dari gigi-gigi yang berdekatan Ameloblastoma umumnya muncul pada dekade tiga hingga lima, namun tidak sedikit kasus yang terjad pada berbagai usia dengan rentang yang luas. ${ }^{3}$

Ameloblastoma terbentuk dari neoplasma agresif yang muncul dari sisa-sisa lamina gigi dan organ gigi (epitel odontogenik). Ameloblastoma merupakan neoplasma sejati dari epitel odontogenik dan neoplasma yang paling umum terjadi. Ameloblastoma memiliki karakteristik pertumbuhan yang agresif tetapi jinak, invasif persisten dan lokal. ${ }^{1}$ Meskipun dianggap tumor jinak, dapat berpotensi menjadi ganas sehingga perlu dipahami secara baik. ${ }^{3}$ Bentuk ganas neoplasma ini adalah malignan ameloblastoma dan ameloblastik karsinoma.

Berdasarkan klasifikasi WHO pada tahun 2005 ameloblastoma secara histologis terbagi menjadi tipe solid/multikistik (konvensional), unikistik desmoplastik dan periferal (ekstraosseous). Tipe solid atau multikistik menjadi jenis yang paling sering ditemukan pada sebagian besar kasus. Kedua tipe ini kemudian pada tahun 2017 telah dilebur menjadi satu yakni tipe konvensional dan banyak studi telah meninggalkan istilah solid dan multikistik oleh karena keduanya menunjukkan pola degenerasi kistik yang sama tanpa perbedaan yang berarti. Ameloblastoma tipe desmoplastik kemudian disetarakan bersama subtipe histopatologis lainnya dan tidak dianggap sebagai tipe besar yang berdiri sendiri secara terpisah, gambaran lain tersebut meliputi folikular pleksiform acanthomatous, granular cell dan basaloid. $^{9,13}$ Ameloblastoma biasanya terlambat didiagnosis karena tidak adanya gejala yang dirasakan dan prevalensi yang rendah. Tantangan dalam melakukan penatalaksanaan pada ameloblastoma adalah untuk mencapai eksisi lengkap dan rekonstruksi defek ketika tumor dalam ukuran sangat besar. ${ }^{5}$ Kasus rekurensi ameloblastoma telah banyak dilaporkan akibat perawatan yang inadekuat. Strategi untuk mencapai keberhasilan pengobatan secara utuh menjadi suatu hal yang penting untuk diperhatikan melalui diagnosis dini secara tepat. ${ }^{6}$

Radiograf panoramik merupakan salah satu tahapan pemeriksaan penunjang diagnosis pertama yang biasanya dipilih dan digunakan para praktis 


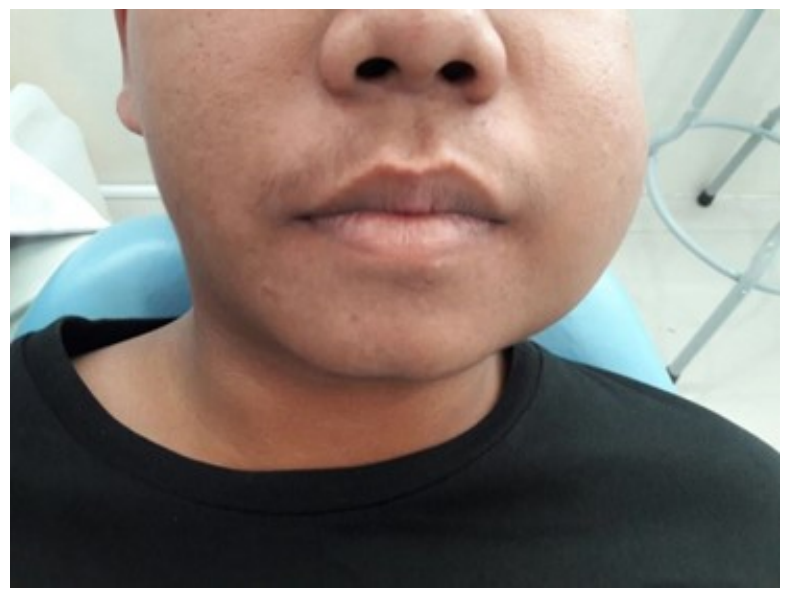

Gambar 1. Keadaan esktraoral pasien menunjukkan adanya asimetri wajah dan pembesaran pada mandibula kiri
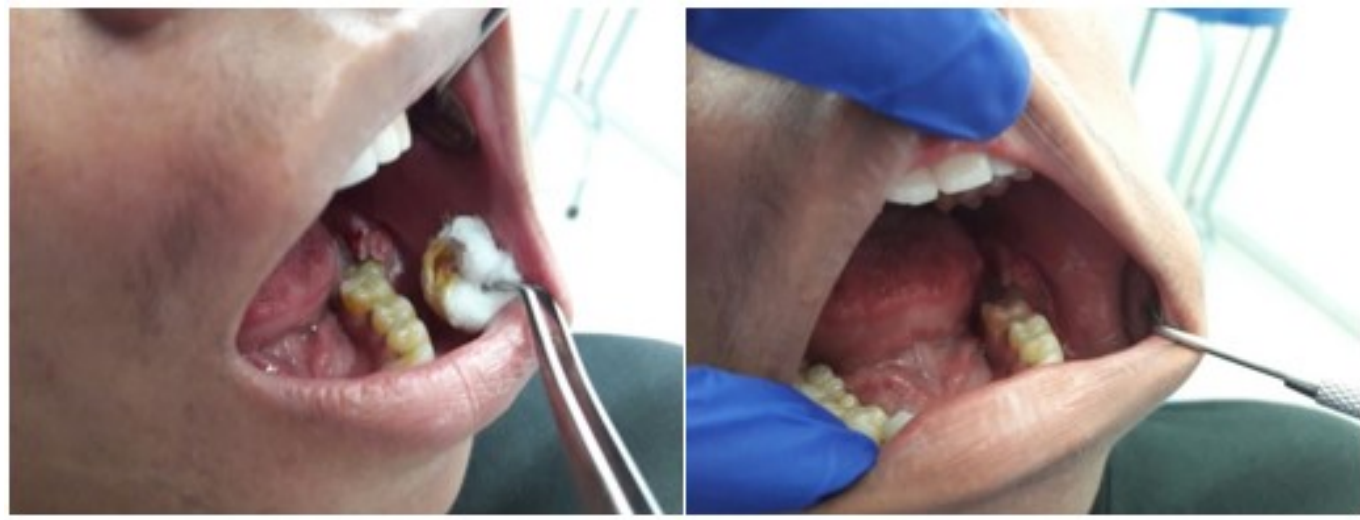

Gambar 2. Pemeriksaan intraoral pasien menunjukkan adanya lesi yang meluas pada gingiva bukal

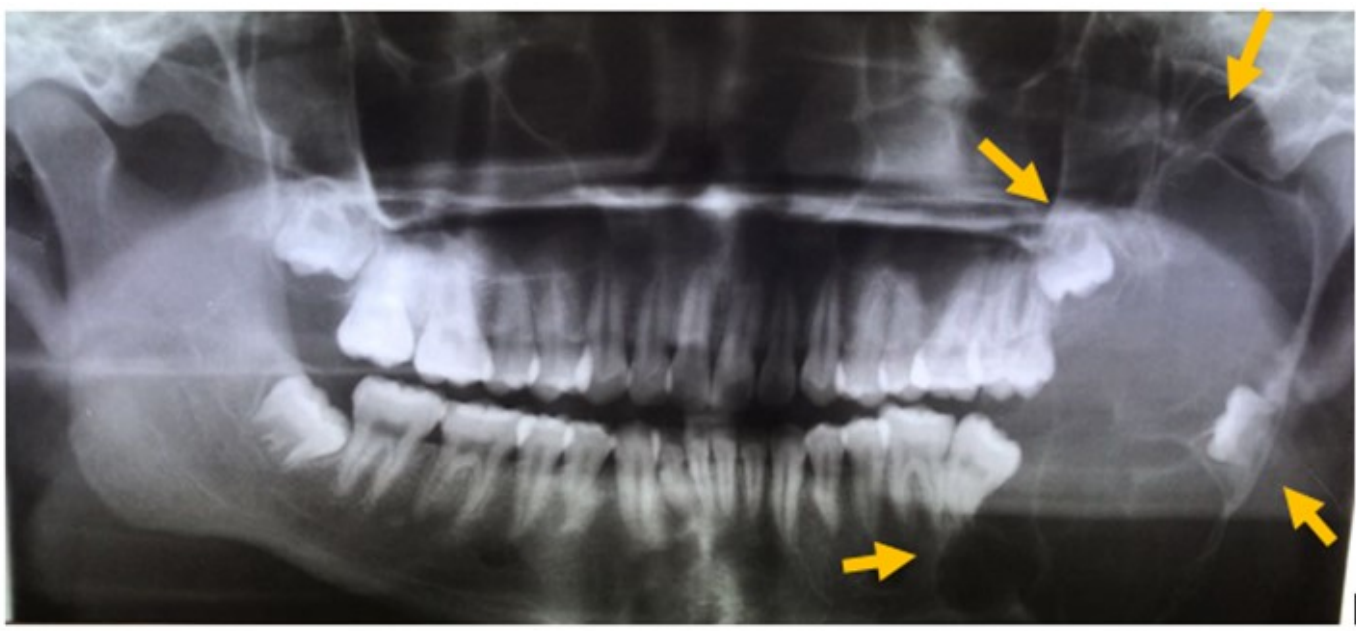

Gambar 3. Radiografi panoramik menunjukkan adanya lesi ameloblastoma dengan pola soap-bubble pada regio posterior kiri mandibular

karena mudah, cepat dan non-invasif dalam ameloblastoma dapat memberikan gambaran mendeteksi suatu kelainan patologis dengan lapang sebagai lesi radiolusen unilokular ataupun pandang yang cukup luas. Banyak diagnosis dini multilokular dengan bentukan khas soap-bubble terdeteksi lewat radiograf walaupun harus (menyerupai busa sabun) ataupun honeycomb dilakukan pemeriksaan penunjang lebih lanjut. (menyerupai sarang lebah). ${ }^{5}$ Tujuan penulisan Pengobatan dapat berubah sehubungan dengan artikel ini adalah untuk menganalisis gambaran variasi gambaran radiologi, lokasi anatomi dan ameloblastoma melalui radiograf panoramik yang perilaku klinis tumor. Faktor penting lainnya adalah ada dalam laporan kasus yang akan dijabarkan serta bergantung pada usia dan kondisi kesehatan umum mengkaji lebih lanjut mengenai macam variasi pasien. $^{4} \quad$ Dalam radiografi konvensional, gambaran radiografi ameloblastoma lainnya. 


\section{LAPORAN KASUS}

Pasien laki-laki berusia 39 tahun yang datang ke RS Dadi Keluarga Purwokerto dengan keluhan pembengkakan pada rahang bawah posterior kiri. Pembengkakan tidak disertai rasa sakit. Pasien belum pernah berobat ke dokter gigi untuk konsultasi pembengkakan tersebut. Dari hasil pemeriksaan ekstra oral terlihat asimetri wajah pada mandibular posterior kiri yang menyebabkan pipi bagian sebelah kiri menjadi lebih besar daripada pipi sebelah kanan (Gambar 1). Palpasi pada area pembengkakan keras. Pada pemeriksaan intra oral ditemukan pembengkakan gingiva pada region posterior dari distal gigi 46 (Gambar 2). Gingiva terdapat ulkus, berwarna merah jambu disertai mukosa berwarna keputihan. Pembengkakan di mandibula posterior menyebabkan gigi 47 terdesak ke subgingiva. Pasien kemudian disarankan untuk melakukan pemeriksaan radiografi panoramik. Metode penelitian ini adalah deskriptif, dengan menganalisa gambaran kasus ameloblastoma dari hasil pemeriksaan radiografi panoramik pasien yang datang ke Rumah Sakit Dadi Keluarga Purwokerto.

Hasil radiografi panoramik (Gambar 3) menunjukkan adanya lesi radiolusen yang terdefinisi dengan baik (well-defined), berukuran cukup besar, ekspansif, multilokular, melibatkan posterior kiri mandibula dan meluas hingga processus koronoid. Lokasi lesi terlihat dari gigi 47 sampai gigi 28 , unilateral serta terdapat penipisan tulang kortikal. Bentuk dari lesi berupa multilokular dengan pola khas dari ameloblastoma yaitu bentukan soap-bubble. Struktur internal lesi tampak tampak radiolusen dengan septa radioopak yang terdefinisi dengan baik.

Penatalaksanaan pada kasus ameloblastoma ini selanjutnya adalah dengan melakukan bedah reseksi mandibula sebelah kiri serta pencabutan gigi 28, 36, 37 dan 38. Prosedur bedah tersebut harus mempertimbangkan risiko akan kecenderungan terjadinya rekurensi pada kasus ameloblastoma ini oleh karena adanya kemungkinan neoplasma telah menyerang tulang yang berdekatan di luar batas yang tampak dalam radiograf. ${ }^{1}$

\section{DISKUSI}

Ameloblastoma pada mandibula dapat berukuran 1-16 cm dan menyebabkan asimetri wajah, perpindahan gigi, maloklusi dan fraktur patologis. ${ }^{5}$ Dalam kasus ini pemeriksaan klinis pasien juga mengungkapkan adanya pembengkakan yang cukup besar dengan konsistensi keras pada posterior mandibular kiri sehingga menyebabkan asimetri wajah, gigi molar yang terdesak ke dalam, dan ekspansi dari gigi molar bawah kir mencapai processus koronoid dan mandibular notch.

Sebagian besar ameloblastoma (80\%) berkembang di wilayah molar ramus mandibula, tetapi mereka dapat meluas ke area symphysis. Prevalensi lesi ini terjadi lebih sering pada pria, dan berkembang lebih sering di Afrika Amerika. Meskipun dapat ditemukan pada anak-anak muda (3 tahun) dan pada individu yang lebih tua dari 80 tahun, kebanyakan pasien berusia antara 20 sampai 50 tahun, dengan usia rata-rata pada penemuan sekitar 40 tahun. ${ }^{1} \mathrm{Hal}$ ini sesuai dengan laporan kasus yang disampaikan, dimana pasien adalah laki-

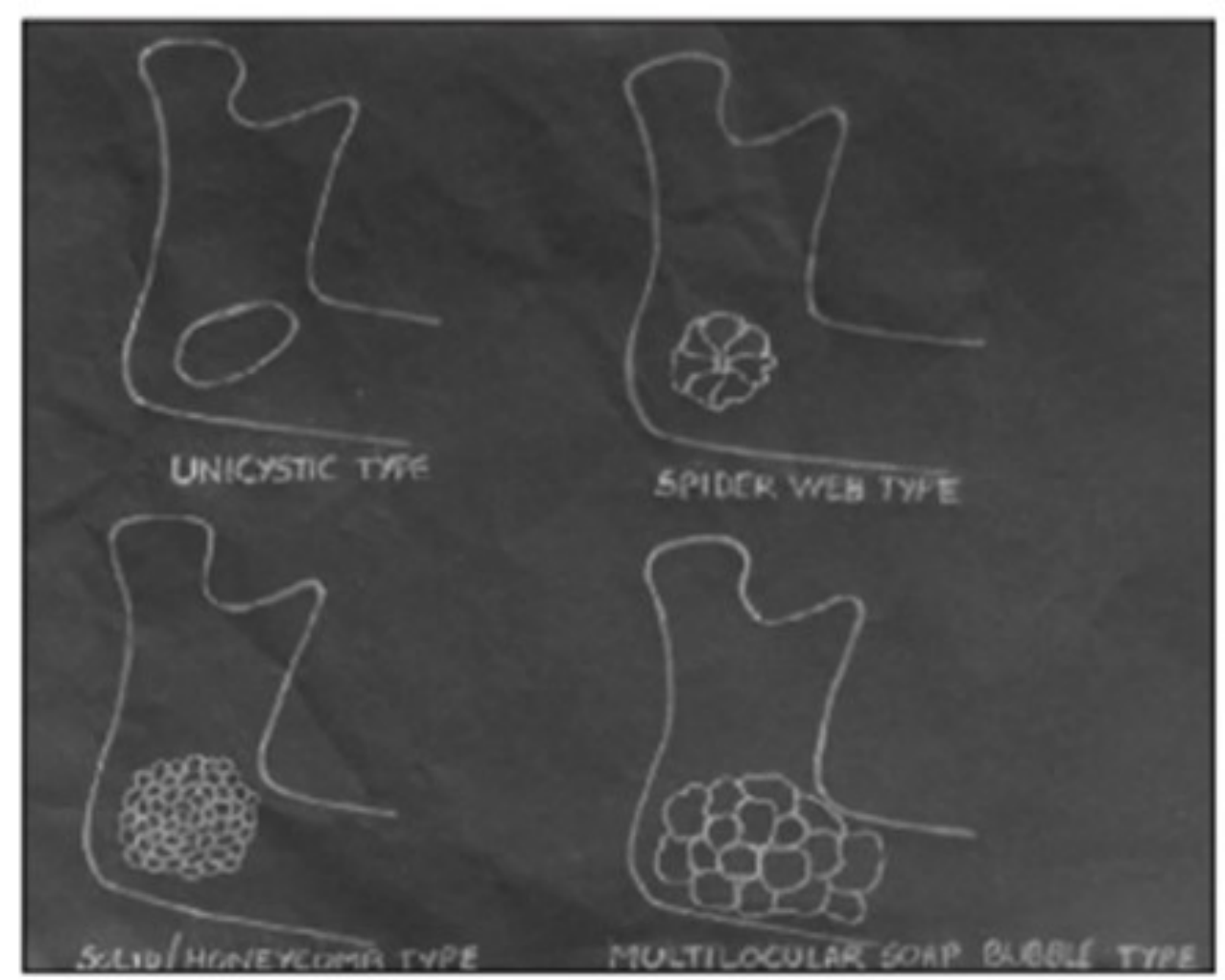

Gambar 4. Skema penampilan macam-macam pola ameloblastoma pada radiograf $f^{5,8}$ 


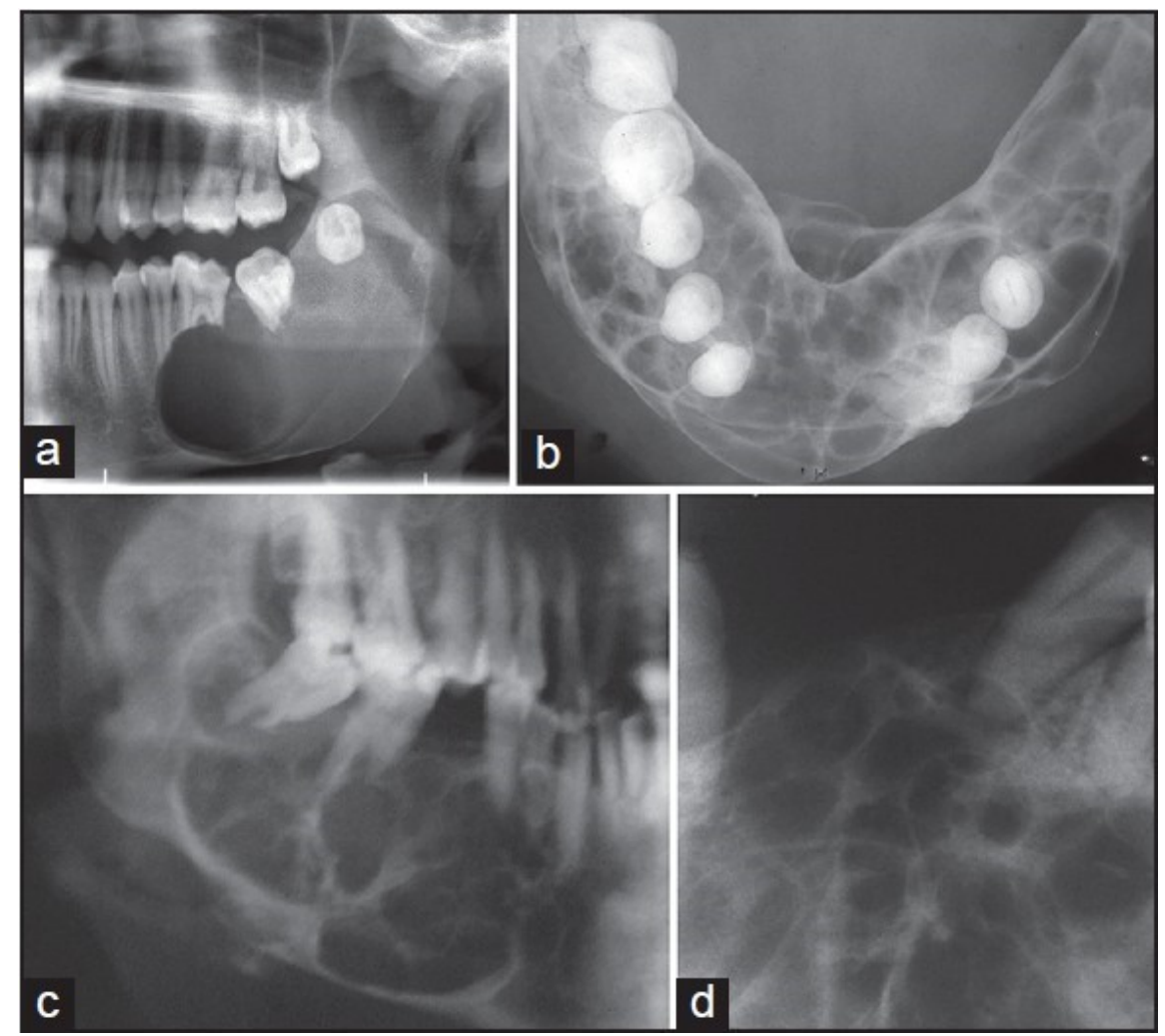

Gambar 4. Penampilan macam-macam pola ameloblastoma pada radiograf,

(A) tipe unikistik, (B) spider-web, (C) soap-bubble dan (D) honeycomb ${ }^{11}$

laki berusia 39 tahun. Lokasi lesi ameloblastoma pada kasus ini terletak dari molar mandibular kiri.

Struktur lesi ini dapat dideteksi menggunakan radiografi panoramik. Radiografi panoramik mungkin lebih disukai daripada computed tomography (CT) ataupun cone beam CT (CBCT). Namun, radiografi panoramik tidak memadai dan direkomendasikan untuk melihat lokalisasi lesi secara keseluruhan karena prinsip kerja radiografi panoramik merupakan gabungan dari beberapa gambar yang diproyeksikan ke dalam satu bidang datar sehingga dapat menjadi kurang tajam dan muncul adanya bentukan ghost image. CT biasanya berguna untuk menentukan kontur lesi, isi, dan perluasannya ke dalam jaringan lunak. MRI adalah radiografi penunjang yang penting lainnya yang dapat digunakan untuk menetapkan tingkat perluasan ameloblastoma apabila dicurigai meluas hingga sinus maksilaris. ${ }^{1,} 7$ Pada kasus ini tidak dilanjutkan pengambilan radiograf CT atau radiografi lanjutan lainnya karena peralatan yang belum memadai, dan secara radiografi panoramik lesi sudah cukup jelas menggambarkan karakteristik dari lesi ameloblastoma.

Secara radiograf ameloblastoma dapat tampak unilokular atau multilokular dan secara histologis dapat muncul sebagai unikistik atau multikistik. Kedua bentuk dapat muncul sebagai kasus rekurensi, khususnya setelah perawatan bedah yang tidak memadai. Radiografi oklusal dapat menunjukkan ekspansi seperti kista dengan penipisan hingga perforasi lempeng kortikal yang berdekatan dan menyisakan lapisan tulang yang tipis menyerupai cangkang telur 'egg-shell'. 1,7,12

Karakteristik dari ameloblastoma secara radiografi pada mandibula biasanya well defined, terkortikasi, beberapa menampilkan scalloped. Sebaliknya, pada maksila, margin ill-defined karena lesi cenderung tumbuh sepanjang tulang daripada melebar. Struktur internal bervariasi dari radiolusen sampai mixed dengan kehadiran tulang septa menciptakan kompartemen internal. ${ }^{1,7}$ Lesi umumnya menyebabkan pergeseran gigi dan destruksi kanalis alveolaris inferior hingga mendesak ruang sinus maksilaris. Selain itu ameloblastoma seringkali mengakibatkan resorpsi gigi di sekitarnya secara ekstensif, dapat berupa resorpsi melintang di tengah apikal gigi hingga meruncingnya apikal. ${ }^{8}$

Struktur internal bervariasi. Septa biasanya kasar dan melengkung dan berasal dari tulang normal yang dimilikinya terperangkap di dalam tumor. Dengan pertumbuhan atau ekspansi dari tumor, mungkin ada perpaduan dan fusi dar kompartemen dan sebagai hasilnya, kemungkinan ada transformasi dari ruang kista multilokular ke unilokular. Tumor dimana kompartemennya besar dan jumlahnya sedikit menyerupai kista epitel multilokular. ${ }^{1,7}$ Variasi gambaran ameloblastoma secara radiografi menurut $\mathrm{H}$. M. Worth dibedakan menjadi empat tipe sebagai berikut; ${ }^{7,8,11}$

Tipe Unikistik, muncul sebagai radiolusensi unilokular menyerupai kista. Namun, tidak seperti kista, ameloblastoma umumnya menyebabkan kerusakan atau diskontinuitas korteks perifer dan bahkan menunjukkan trabekula di dalam lumen.

Pola spider-web, tampilan ini yang paling sering umum, dimana lesi terlihat sebagai area radiolusen yang besar dengan batas tepi menyerupai scalloped. Pusat lumen batang trabekula kasar 
memancar ke perifer, menimbulkan gambaran kasar menyerupao laba-laba.

Pola soap-bubble, lesi ini terlihat sebaga radiolusen multilokular dan memiliki ruang-ruang yang besar dengan berbagai ukuran, menimbulkan penampilan gelembung sabun atau multichambered atau tampilan multicystic 'bunch of grapes'.

Honeycomb atau pola solid, pola ini disebut juga sebagai pola sarang lebah. Tumor belum mengalami degenerasi kistik. Oleh karena itu, banyak radiolusen kecil-kecil yang terlihat dikeliling oleh heksagonal atau korteks tulang berdinding tebal polygonal, sehingga menimbalkan tampilan yang menyerupai sarang lebah.

Ameloblastoma pada laporan kasus ini termasuk ke dalam tipe multikistik dengan pola soap-bubble. Hal ini mencirikan bahwa les ameloblastoma bersifat ekspansif dan telah mengakibatkan tulang kortikal terdorong secara eksentrik disamping proses osteolitik yang terjadi. Adanya gambaran septa internal menandakan bagian tulang yang terperangkap akibat terdorong oleh lesi ameloblastoma. Tulang tersebut kemudian menjadi suatu bentukan panjang yang mengikuti dinding lesi hingga akhirnya terbentuk septa. Pola soap-bubble ini dapat mencirikan terdapatnya bentukan kistik di tingkat histologis karena gambaran pembentukan septa tersebut telah membentuk tulang menjadi bentukan melengkung yang serupa dengan sifat kista. Ketika lesi menjad lebih agresif maka dapat terjadi perforasi. Pemeriksaan mendalam pada area puncak retromolar dan batas anterior ramus menjadi ha yang patut dilakukan. ${ }^{1}$

Dalam beberapa studi radiologis dilaporkan bahwa ameloblastoma unilokular lebih banyak ditemukan pada usia muda, bagaimanapun temuan tampakan multilokuler pada lesi ameloblastoma jauh lebih mendominasi secara keseluruhan dibandingkan bentukan unilokuler. Para klinisi wajib memahami berbagai manifestasi ameloblastoma. Ameloblastoma unilokular dengan ukuran keci yang terletak di sekitar mahkota gigi yang tidak erupsi sering tidak dapat dibedakan dari kista dentigerous. ${ }^{10}$ Penampilan septa tulang internal penting dalam mengidentifikasi suatu ameloblastoma, jenis lesi lain yang juga memiliki septa internal, yaitu odontogenic keratocyst, granuloma giant sel, odontogenic myxoma dan ossifying fibroma. Odontogenic keratocyst umumnya memiliki septa yang melengkung (scalloped-border) dan cenderung tumbuh di sepanjang tulang tanpa menimbulkan ekspansi yang merupakan karakteristik ameloblastoma Granuloma giant sel terjadi pada kelompok usia yang lebih muda dan memiliki septa yang lebih granular atau tidak jelas. Odontogenic myxoma mungkin memiliki septa yang tampak serupa, namun biasanya ada satu atau dua, septa lurus, tajam tipis yang mencirikan karakteristik dari myxoma. Septum myxoma tidak terlalu luas seperti ameloblastoma dan cenderung tumbuh di sepanjang tulang. Septa pada ossifying fibroma biasanya lebar, granular, dan tidak jelas, dan sering terdapat trabekula kecil, tidak teratur. ${ }^{1}$
Mengenali variasi dan pola gambaran ameloblastoma secara radiografi, khususnya menggunakan radiografi panoramik yang merupakan salah satu tahapan pemeriksaan penunjang awal, menjadi hal yang penting guna mendapat diagnosis ameloblastoma secara dini sehingga diharapkan dapat mencegah terjadinya perawatan yang inadekuat dan munculnya kasus rekurensi. Pada sebagian kecil kasus, ameloblastoma dapat bertransformasi menjadi lesi keganasan seperti ameloblastik karsinoma ataupun malignan ameloblastoma. Hal-hal yang harus diperhatikan dan menjadi poin penting secara radiografis tersebut meliputi lokasi lesi, batas dan bentuk lesi, struktur internal, pola septasi hingga keadaan jaringan di sekitar lesi, mulai dari keadaan gigi-gigi sekitar hingga penipisan lempeng kortikal. Pemeriksaan menggunakan modalitas radiografi lanjutan mungkin diperlukan agar dapat melihat perluasan lesi secara lebih akurat.

\section{SIMPULAN}

Radiografi merupakan penunjang diagnosis yang penting untuk berbagai jenis lesi oral, terutama yang melibatkan tulang. Radiografi panoramik dapat digunakan untuk menganalisis lesi ameloblastoma pada tahap awal. Biasanya ameloblastoma tidak memiliki gejala dan dilakukan karena pasien mengalami perubahan asimetri wajah. Meskipun diagnosis ameloblastoma sangat sering ditetapkan atas dasar fitur radiograf, sebaiknya lesi tetap dibiopsi dan didiagnosa secara histologis sehingga hasil diagnosis yang didapat lebih akurat dan komprehensif. Gambaran radiologi ameloblastoma unilokular umumnya campuran. Lesi ameloblastoma yang besar dapat menyebabkan gangguan pada struktur disekitarnya, seperti asimetri wajah, malposisi gigi, resorbsi akar, penipisan tulang kortikal, dan invasi ke jaringan lunak sekitar lesi. Pengetahuan mengenai manifestasi klinis dan bermacam pola ameloblastoma secara radiografis menjadi penting sehingga dapat mencegah kesalahan dalam diagnosis ataupun perencanaan perawatan.

\section{DAFTAR PUSTAKA}

White SC, Pharoah MJ. Oral Radiology Principles and Interpretation. 7th. rev. ed. St. Louis: Elsevier Mosby, 2014 $366 \mathrm{p}$.

2. Wadhawan R, Sharma B, Sharma P, Gajjar D. Unicystic ameloblastoma in a 23 year old male: A case report. International Journal of Applied Dental Sciences 2016; 2(4): 87-92.

3. Medeiros $\mathrm{M}$, Porto GG, Filho JRL, et al. Ameloblastoma in the Mandible. Rev Bras Otorrinolaringol 2008; 74(3):478

4. Gumgum S, Hosgoren B. Clinical and Radiologic Behaviour of Ameloblastoma in 4 Cases. J Can Dent Assoc 2005; 71(7):481 4

5. Worth H. Principles and practice of Oral Radiographic Interpretation. Year Book Medical Publishers Copyright; 1963. p. $476-88$.

6. Suma MS, Sundaresh KJ, Shruthy R, Mallikarjuna $R$. Ameloblastoma: an aggressive lesion of the mandible. BM Case Rep 2013.

7. Masthan KMK, Anitha N, Krupaa J, Manikkam S 
Ameloblastoma. J Pharm Bioallied Sci. 2015 Apr; 7(Suppl 1): S167-S170.

8. More C, Tailor M, Patel HJ, et al. Radiographic analysis of ameloblastoma: A retrospective study. Indian Journal of Dental Research, 23(5), 2012.

9. Rahman FUA, Yunus B, Rasul I, Faisal. 2019. Radiological analysis and postoperative evaluation of multilocular ameloblastoma in young patient through panoramic radiograph: a case report. Journal of Case Reports in Dental Medicine 1(3): 73-76. DOI: 10.20956/jcrdm.v1i3.99

10. Sheela S, Singer SR, Braidy HF, Alhatem A, Creanga AG. Maxillary ameloblastoma in an 8-year-old child: A case report with a review of the literature. Imaging Science in Dentistry. 2019 Sep;49(3):241-249. DOI: 10.5624/isd.2019.49.3.241.

11. Tatapudi R, Samad SA, Reddy RS, Boddu NK. Prevalence of ameloblastoma: A three-year retrospective study . J Indian Acad Oral Med Radiol 2014;26:145-51.

12. Kamath, J. S., Kini, R., \& Naik, V. Solid Multicystic Ameloblastoma Misdiagnosed Radiographically as a Periapica Cyst: A Case Report. J Dent Indones. 2018;25(1): 65-68.

13. Yoithapprabhunath, T. R., Nirmal, R. M., Ganapathy, N. Mohanapriya, S., Renugadevi, S., Aravindhan, R., \& Srichinthu, K. K. (2019). Meta-terminology of Ameloblastoma. Journal of pharmacy \& bioallied sciences, 11(Suppl 2), S140-S145. https://doi.org/10.4103/JPBS.JPBS_57_19 